\title{
Women Organizations Agenda Setting and Policy Outputs in The Education Sectors of Ghana And Liberia
}

\author{
Adebusola Morenikeji ODEDINA; Ngozi NWOGWUGWU*, PHD \\ Department of Political Science and Public Administration, Veronica Adeleke School of Social Sciences, \\ Babcock University, Ilishan-Remo. \\ *Correspondence email: nwogwugwun@babcock.edu.ng
}

\begin{abstract}
Women organizations agenda setting ensure that women issues are given priority in the policy process leading policy outputs that address sectors that of special interest to women. The education sectors of countries are regarded as priority sector given that educates one of the key parameters for measuring human development in countries. Ghana and Liberia currently rank low in the global human development index. The study examined the effect of women organizations agenda setting on policy outputs in the education sectors of Ghana and Liberia. Survey design was adopted, while the population of study was women organizations in Ghana and Liberia. Data were analyzed using descriptive and inferential statistics. The study found that women organizations agenda setting has joint significant positive effect $F(1,677)=8453.559$, Adj. $R^{2}=0.962, p<0.05$ on policy outputs in the education sectors in Ghana and Liberia. However, the effect is more positive in Liberia than in Ghana. Government of both countries need to adopt quota system that would ensure greater representation of women legislature and decision making roles to ensure improved impact of women agenda setting roles on policy outputs.
\end{abstract}

Key words: women organizations, agenda setting, education sector, policy outputs

DOI: $10.7176 /$ PPAR/10-2-06

Publication date: February $29^{\text {th }} 2020$

\section{Introduction}

Women's organizations are organizations that are composed of women and are funded by women or men that are established for the purpose of pursuing women's liberation, gender equality and social justice in any given society (Olojede, 2008). They are organizations that seek to further women's rights by addressing the issues of human rights of both women and men. Women's organizations encompass different categories of women groups including non-governmental organizations (NGOs), community based organizations (CBOs), civil society organizations (CSOs) and other groups that are focused on achieving gender equality, as well as ensuring women's economic political and social development (Afolabi 2019).

Women organizations also pursue the upliftment and empowerment of women for self and national development. They undertake programmes that support the overall growth and development of women leaders in their countries worldwide. Some women's organizations have as their principal objective the increase of women's representation in government (both parliament and the executive) and they execute programmes that seek to bridge the gender in elective and appointive positions (African Women Power Network Reviews, 2015).

In societies that are undemocratic and oppressive, women organizations ensure that women's rights are defended. Even, in democratic societies, where women face difficulty in accessing justice, women's organizations are usually active in providing direct support to women in form of legal aid thereby ensuring that they have justice and their human rights are not trampled upon (Afolabi 2019).

According to Afolabi (2019), females by their uniqueness, have experiences that are completely different from their male counterparts, and as such women organizations seek to ensure that women are involved in the policy process in order to ensure that their needs are met through the policy outputs of government. As a result of the fact that the interests of men and women are conflicting, women representation in both parliament and executive are necessary in order to ensure adequate support women's concerns and interests. Women organizations there work to ensure women representation in public space given the large proportion of women across various societies.

Generating Policy outputs that meets the needs of the citizens, is what government responsiveness refers to. Indeed, many have argued that responsiveness is a key aim for democracies and that a core source of legitimacy originates from the policy output side (Rothstein, 2011). When governments are able to give people what they want in terms of policy output, the government will in turn enjoy the support of the citizens, which confers legitimacy on the government (Dahlberg, Linde, \& Holmberg, 2015). The policy outputs of government should be favorable to the affected citizens (Estlund, 2009), or at least perceived by the citizens as fair and unbiased 
(Hibbing \& Theiss-Morse, 2002; Rothstein, 2009). In essence, people tend to be satisfied when they get what they want, encouraging popular legitimacy.

In every society, basically what the government decides to do or not to do is referred to as public policy and it usually has direct impact on the people (Ishola and Nwogwugwu 2019). The output of the policy process, which is the policy output, is expected to address specific needs of the citizens. Given that women have unique needs, the policies of government must also be context specific and gender disaggregated in order for it to be able to meet the needs of the women. This is why women organizations engage in advocacy activities, insisting on greater women involvement in the policy making process in order to ensure that the core areas of interest to women are addressed by the policy outputs of government.

As such, women organizations in Ghana and Liberia are expected to engage in activities that provide access to public officials and institutions, with a view to influencing government actions and policies. They also engage in agenda setting activities that seek to make women issues priority of government policy outputs on women related issues. The fact that less than one out of five legislative seats worldwide is occupied by a woman can have serious repercussions for policy. The study examined the strategies and methods utilized in mobilizing women by women organizations for active participation in the political process in Ghana and Liberia; investigate the influence of women organizations agenda setting and accountability measures on policy outputs in the education sector in Ghana and Liberia.

\section{Literature Review}

2.1 Women Organizations

Women organizations seek to achieve increased involvement of women on equal terms with men at all levels of decision making. This is regarded as key to the achievement of equality and development, peace as well as democracy. The activities of women organizations also encourage incorporation of women's perspectives and experiences into decision making that could enhance satisfactory solutions not only for the women but the society at large (Kassa, 2015). Women organizations have been attributed as having made remarkable contributions towards the rise in women's political participation in the world, including Africa, as they have championed access to education not only for the girl child, but the men as well. Women organizations have championed the adoption of gender affirmative action plans leading to adoption of quota system in several countries. Various Organizations both local and international have been advocating for greater involvement of women in political decision making (Ocran 2014).

Various women organizations both national and international are engaged in capacity building programmes for female politicians and candidates for office in line with the propositions of Asiedu, Branstette, GaekwadBabulal, and Malokele, (2018), Page (2018) and Iloren (2015) who propose that it is only through strengthening and advancing women political inclusion through education for aspiring women into politics and governance, quota, legislation, financing and grassroots empowerment that such women can make meaningful impact in terms of addressing women interests while in office.

The major platform through which most women participate actively in politics and governance is the membership of the women organizations. Beyond mobilizing their members to vote during general elections, the women organizations also utilize such mechanisms as access, agenda setting, and accountability measures to influence policy output in the pro-women sectors.

Access refers to the ability of women to enter the state, both in the electoral arena as well as the policy arena. Access can be attained through a variety of means. In the electoral arena, strategies include the use of quotas, reserved seats, party influence and global norm-setting through multinational agreements (such as the Southern Africa Development Community (SADC) Protocol on Gender and Development). In the policy arena, governments may invite women's participation, women's movements may challenge policies that discriminate against women in consultative processes and most commonly in Africa, special mechanisms collectively known as national gender machineries can offer institutionalized access to policy making processes. In the parliamentary arena, access can range from the ability to make submissions to government on upcoming legislation, attending public hearings on legislation, to one on one discussions with members of parliament. Access is also the beginning of a process of keeping government accountable for its actions toward a constituency of women.

The extent to which women can obtain political access is largely influenced by a society's political culture, cultural attitudes, identity politics as well as the economic barriers that accompany gender roles. The nature of 
the political system (whether it is democratic, authoritarian or a dictatorship) has a direct impact on the number of political parties that are recognized for contesting of elections, as well as the dynamics of electoral contest in such countries. The electoral system will determine how, and how many, women get into parliament. Even in democratic countries that are signatories to affirmative action, it is important to note that "formal commitments to equal participation may not translate into more seats in parliament. In situations of nation building, contestations between the interests of including women and acknowledging ethnic particularities play a role in the outcomes of representation" (Agbalajobi, 2010, p. 77). Some countries in recognition of the fact that more than formal recognition of international protocols are required to ensure gender equality have adopted quotas as mechanism for breaking through entrenched barriers to women's participation. In the policy arena, National Gender Machineries are important structures that can support women in government and provide access to the structures in which the key priorities of governments are set. However, their effectiveness in terms of access depends on the extent to which women are allowed to participate in Cabinet (for example) as full members. Large number of countries including Ghana and Liberia try to appointment women to various political offices, although the ratio of cabinet positions still remains low.

One of the ways to determine whether women leaders make a difference is to observe whether they are able to set a feminist agenda, or an agenda that will advance gender equality. Agenda setting can be viewed as the process through which government priorities are set, and needs or problems are given attention from the government.

Flammang (1997) distinguishes between a systemic agenda (issues that fall within the legitimate concern of governments, meriting its attention) and a legislative agenda (the institutional agenda of law makers) (Kenney, 2003). The legislative agenda always lags behind the systemic agenda and it is therefore important that issues identified in the systemic agenda are kept alive until they reach lawmakers. This process is aided by what Flammang (1997) calls issue publics in four different categories: (1) identification group (those who identify the issue), (2) attention group (those who pay attention to the issue), (3) attentive public (those who have a stake in it), and (4) general public (those who are less informed and less involved).

Women political leaders can bring gender equality issues to the legislative and systemic agendas by acting in the first two publics when they identify issues and mobilise those who pay attention to the issue. For this reason, it has been demonstrated that agenda setting processes are more effective when women in government are part of women's policy networks outside government. This is linked to the different roles political and civil society actors play in different publics.

Applying this framework to the African context, it is evident that different political cultures and unevenness in the role of parliaments can affect the relationship between systemic and legislative agendas. For example, legislation to end formal discrimination may be more easily achieved in contexts where demonstrating commitment to gender equality is part of the government's official stance, but there may be far less support for integrating these concerns into actual policies.

When it comes to gender equality, Walby (2005, p. 323) argues that we should distinguish between approaches that are "agenda setting" and those that are "integrationist". According to Walby (2005), agenda setting implies the transformation and reorientation of existing policy paradigms, changing decision making processes, prioritizing gender equality objectives and rethinking policy ends. In this approach it is the mainstream that changes. Integrationist approaches are those that introduce a gender perspective without challenging the existing policy paradigm. It is clear that an agenda setting process will have a transformative effect on policy making. Women organizations' agenda setting approaches offer the opportunity to put women's issues at the core of the public policy process, ensuring that women issues enjoy equal attention as those that are principally male oriented (Ishola, Nwogwugwu, Nwaodike and Ogu, 2019). But this type of agenda setting implies leadership that will be able to pay attention to the goals of women's movements, gender equality and women's empowerment as articulated by the women's movement. In their agenda setting activities women must ensure that priority is given towards strengthening women's agency and women organizations (Jahan, 1996).

Because an agenda for equality should reflect the needs and demands of women, agenda setting processes should also involve consultation in the form of research and public opinion surveys. The aim would be to get information that could inform government of women's grievances and demands that subsequently can be rectified through well-targeted government action. Optimally, this is also an avenue through which strategies that empower women in communities can be presented as alternatives to top-down delivery of goods and services.

Agenda-setting can be thought of as the culmination of women's engagement with civil society, politics and the 
state, a process which integrates the voices of women into policy making and impacts the operation of the legal system and service delivery. It should, optimally, lead to accountability toward a constituency of women (Goetz, 2003, p 38-41). Setting the equality agenda therefore should be a cooperative effort between women within the state apparatus and women as non-state actors.

\subsection{Policy Outputs}

Policy output is composed on three levels of abstraction: the goals of policies, the instruments used to achieve these goals, and the settings in which the policies are applied (Howlett \& Cashore, 2009). The goals of the policy must target the needs of the citizenry who elected the government, and who the government exists to serve. Policy instruments are described as "building blocks" or means to transfer the rather abstract principles and rules set out by policies into concrete and substantive action (May, 2003, p. 225) and are, therefore, located at the center of the taxonomy ("mechanisms"). Each policy instrument comprises a wide range of intensity measures, such as objectives, the tools to reach these objectives, benefits and burdens affecting the target populations, and rationales legitimizing the implementation structures (Bobrow, 2006; Schneider \& Sidney, 2009).

Government institutions and agencies adopt different mechanism in their efforts at implementing policies. These mechanisms are designed to reach the set objectives or targets of the policies which is usually to meet the needs of the citizenry (Howlett \& Lejano, 2012; May, 2003; Schneider \& Sidney, 2009). Several scholars have adopted such mechanism as study of policy change (Howlett \& Cashore, 2009; Jones \& Baumgartner, 2012), policy diffusion (Carley \& Miller, 2012), theories of the policy process (Weible, Heikkila, deLeon, \& Sabatier, 2012), or analyses of policy outcome (Jahn \& Kuitto, 2011; Knill et al., 2012) as avenue for analyzing policy output in the context of the policy portfolio, i.e., the entirety of all instruments adopted and active in a policy field (Howlett, 2014).

In conceptualizing the "intensity" of policy instruments, such terms such as "importance," "significance," or "stringency" are to provide measureable standards for policy output (Carley \& Miller, 2012; Holzinger et al., 2011; Grant \& Nathan, 2008). Policy intensity can be defined as the "organization and mobilization of resources" (Albrecht \& Arts, 2005, p. 888), i.e., the amount of resources, effort, or activity that is invested or allocated to a specific policy instrument. These resources reflect the level of importance that is credited to a specific policy instruments, as well as the objectives and political context of the policy (Howlett \& Cashore, 2009).

\section{Theoretical Framework}

3.1 Rational Choice Theory

The Rational-choice theory (RCT), which is sometimes called social-choice, public-choice, or formal theory, originated with economists and involves applying the principles of micro-economic theory to the analysis and explanation of political behaviour (or nonmarket decision-making) (Anderson, 1997).

Anthony Downs is credited with being the first political scientist to apply it in the study of the political process in his Economic Theory of Democracy published in 1957. Downs (1957) assumes that voters and political parties act as rational decision-makers who seek to maximise attainment of their preferences. Parties formulate whatever policies will win them most votes and voters, and seek to maximise the portion of their preferences that could be realised through government action. In attempting to win elections, political parties move toward the centre of the ideological spectrum to appeal to the greatest number of voters and maximise their voting support. Thus, rather than providing meaningful alternatives, parties will become as much alike as possible, thereby providing an ,echo rather than a choice ${ }^{e e}$ (Downs, 1957).

According to Anyebe (2018), the rationalist model deals with construction of public policies that ensure better public policies. It thus aims at improving public policy-making process. The rationalist model is conceptually quite simple. Policy-makers using it are expected to take the following steps:

Identify all the value preferences currently existing in a society.

Assign each value a relative weight,

Discover all the alternative policies available to accomplish these values,

Know all the costs and consequences of each alternative policy,

Select the best alternative which is also the most efficient in terms of the costs and benefits of social values (Anyebe 2018, p. 16). 
In order to follow the steps stated, the rational-choice theory according to Ikelegbe (1996 cited in Anyebe 2018) assumes the following:

That perfect information can be obtained for example, to objectively assess policy alternatives; that there is commonality of values and preferences particularly in the setting of goals and objectives, that the rational actor thinks of the greatest good of the greatest number as a guide to decision-making, that objectives and alternatives can be quantified and compared on a single monetary measure; that the conditions and parameters for the decision are static within the decisionmaking period. There is no doubt that these assumptions are simply not realisable in the real world situations, hence making the implementation of the model clearly impossible (p. 16).

Rational Choice Theory (RCT) aims to provide an explanation for the human behaviour in terms of economic rationality. It stresses the role of the individual as 'benefit maximiser' meaning, when presented with decision, individuals will take rational actions. Therefore, making cost efficiency assessments will ensure that the best possible outcome is achieved. Individuals, or political agents, have full access to information and, according to their preferences, will favour the decision that allows them the best possible outcome. Forester (1984) explains that RCT is comprehensive and abstract, for which the decisive factors are information which "is perfect, complete, accessible and comprehensive. Time is infinitely available" (p.25).

\section{Methodology}

The study adopted survey research design. The population of the study is women organizations in Ghana and Liberia. In Ghana, there are 45 registered women organizations while there are 47 registered women organizations that are actively involved in the policy processes in Liberia. The combined total of the membership of the registered women organizations in the two countries is 37,776. Unregistered women organizations were excluded from the research as their contributions to the policy process if any may not be documented, and their number may be infinite. The independent variable is women organizations agenda setting, while the dependent variable is policy outputs in the education sector in Ghana. Education sector was selected because it is among the sectors that attract special interest of women and women groups across the globe. It is also a primary sector that is critical in the measurement of human development of a given country. For the purpose data collection, respondents were selected from membership of the women organizations. The sample size is determined using the Taro Yamane (1970) formula as presented below:

$$
\mathrm{n}=\frac{\mathrm{N}}{1+\mathrm{N}(\mathrm{e})^{2}}
$$

Where $\mathrm{n}$ is the sample size, $\mathrm{N}$ is the population size and $\mathrm{e}$ is the level of precision $(0.03)$

$$
\begin{aligned}
& \mathrm{n}=\frac{37776}{1+37776(0.04)^{2}} \\
& \mathrm{n}=\frac{37776}{1+60.4416} \\
& \mathrm{n}=614.82774 \\
& \mathrm{n}=615 \\
& \text { In other to account for expected attrition, additional } 10 \% \text { is to be added } \\
& 615+61.5=676.5=677
\end{aligned}
$$

The method of data collection was field survey (questionnaire administration). A total of six hundred and seventy-seven copies of the questionnaire (399 for Ghana and 278 for Liberia) will be administered. Respondents were selected using stratified random sampling. Descriptive and inferential statistics (linear regression) were employed in the analysis of data. 


\section{Results and Discussion}

Table 1: Policy Outputs in the Health and Education Sector

\begin{tabular}{|c|c|c|c|c|c|c|c|c|c|}
\hline $\mathrm{S} / \mathrm{N}$ & Statements & Countries & $\begin{array}{l}\text { SA } \\
(\%)\end{array}$ & $\begin{array}{c}\text { A } \\
(\%)\end{array}$ & $\begin{array}{l}\mathrm{D} \\
(\%)\end{array}$ & $\begin{array}{l}\text { SD } \\
(\%)\end{array}$ & $\begin{array}{c}\mathrm{U} \\
(\%)\end{array}$ & Mean & St.D \\
\hline & \multirow[t]{3}{*}{$\begin{array}{l}\text { women organizations agenda setting resulted in } \\
\text { formulation of new education policies }\end{array}$} & Ghana & $\begin{array}{c}6 \\
(1.5) \\
\end{array}$ & $\begin{array}{c}61 \\
(15.3)\end{array}$ & $\begin{array}{c}54 \\
(13.5)\end{array}$ & $\begin{array}{c}126 \\
(31.6)\end{array}$ & $\begin{array}{c}152 \\
(38.1)\end{array}$ & 2.1053 & 1.12037 \\
\hline & & Liberia & $\begin{array}{c}88 \\
(31.7) \\
\end{array}$ & $\begin{array}{c}186 \\
(66.9) \\
\end{array}$ & $\begin{array}{c}2 \\
(.7) \\
\end{array}$ & $\begin{array}{c}2 \\
(.7)\end{array}$ & & 4.2950 & .51621 \\
\hline & & Combined & $\begin{array}{c}94 \\
(13.9)\end{array}$ & $\begin{array}{c}247 \\
(36.5)\end{array}$ & $\begin{array}{c}56 \\
(8.3)\end{array}$ & $\begin{array}{c}128 \\
(18.9)\end{array}$ & $\begin{array}{c}152 \\
(22.5)\end{array}$ & 2.0044 & 1.41786 \\
\hline & \multirow[t]{3}{*}{$\begin{array}{l}\text { women organizations agenda setting led to } \\
\text { specific policies on girl child education }\end{array}$} & Ghana & $\begin{array}{c}10 \\
(2.5) \\
\end{array}$ & $\begin{array}{c}60 \\
(15) \\
\end{array}$ & $\begin{array}{c}48 \\
(12) \\
\end{array}$ & $\begin{array}{c}137 \\
(34.3) \\
\end{array}$ & $\begin{array}{c}144 \\
(36.1) \\
\end{array}$ & 2.1353 & 1.13719 \\
\hline & & Liberia & $\begin{array}{c}88 \\
(31.7)\end{array}$ & $\begin{array}{c}185 \\
(66.5)\end{array}$ & $\begin{array}{c}3 \\
(1.1)\end{array}$ & $\begin{array}{c}2 \\
(.7)\end{array}$ & & 4.2914 & .52173 \\
\hline & & Combined & $\begin{array}{c}98 \\
(14.5) \\
\end{array}$ & $\begin{array}{c}245 \\
(36.2) \\
\end{array}$ & $\begin{array}{c}51 \\
(7.5) \\
\end{array}$ & $\begin{array}{c}139 \\
(20.5) \\
\end{array}$ & $\begin{array}{c}144 \\
(21.3) \\
\end{array}$ & 2.0207 & 1.41406 \\
\hline & \multirow{3}{*}{$\begin{array}{l}\text { Women organizations agenda setting led to } \\
\text { policies aimed at improving quality of } \\
\text { educational services. }\end{array}$} & Ghana & $\begin{array}{c}23 \\
(5.8) \\
\end{array}$ & $\begin{array}{c}60 \\
(15) \\
\end{array}$ & $\begin{array}{l}12 \\
(3) \\
\end{array}$ & $\begin{array}{c}121 \\
(30.3) \\
\end{array}$ & $\begin{array}{c}183 \\
(45.9) \\
\end{array}$ & 2.0451 & 1.26926 \\
\hline & & Liberia & $\begin{array}{c}89 \\
(32) \\
\end{array}$ & $\begin{array}{c}110 \\
(39.6) \\
\end{array}$ & $\begin{array}{c}75 \\
(27) \\
\end{array}$ & $\begin{array}{c}2 \\
(.7)\end{array}$ & $\begin{array}{c}2 \\
(.7) \\
\end{array}$ & 4.0144 & .82808 \\
\hline & & Combined & $\begin{array}{c}112 \\
(16.5)\end{array}$ & $\begin{array}{c}170 \\
(25.1)\end{array}$ & $\begin{array}{c}87 \\
(12.9)\end{array}$ & $\begin{array}{c}123 \\
(18.2)\end{array}$ & $\begin{array}{c}185 \\
(27.3)\end{array}$ & 1.8538 & 1.47289 \\
\hline
\end{tabular}

Table 1 shows the respondents' opinion on policy outputs in the health and education sector. The table reveals that, on the average women organizations agenda setting could not result in formulation of new education policies (mean=2.0044; St. $D=$. 1.41786). However, the effect of women organization agenda setting was better in Liberia than in Ghana. The analysis also shows the average score on women organizations agenda setting leading to specific policies on girl child education in both countries (mean=2.0207; $\mathrm{St} . \mathrm{D}=1.41406$ ). Liberia has a higher mean score, showing positive impact of women agenda setting on formulation of specific policies on girl child education. Women organizations agenda setting led to policies aimed at improving quality of educational services (mean=1.8538; St. $D=1.47289)$. Though the combined average is low, the score for Liberia shows a high score of 4.0144 which is very positive. All the indicators, Liberia had a higher score than Ghana, indicating that women agenda setting had a more positive impact in policy outputs in the education sector in that country. This corroborates early study by Nwogwugwu and Odedina (2018) that the low level of women political participation in Ghana impacts the formulation and implementation of critical policies and programmes in the country with adverse effects on women.

Ho: $\quad$ women organizations agenda setting and accountability measures have no significant effect on policy outputs in the education sector in Ghana and Liberia.

Table 2: Effect of Women organizations agenda setting on policy outputs in Education sectors of Ghana and Liberia

\begin{tabular}{|c|c|c|c|c|}
\hline Variable & Coefficient & Std. Error & t- Statistics & Prob. \\
\hline (Constant) & .057 & .090 & .632 & .528 \\
\hline Agenda setting & 2.839 & .118 & 24.151 & .000 \\
\hline
\end{tabular}

\begin{tabular}{|l|l|}
\hline \hline R-Square & .962 \\
\hline Adjusted R-Square & .962 \\
\hline F-statistics & 8453.559 \\
\hline Prob. (F-statistics) & .000 \\
\hline
\end{tabular}

Dependent Variable: Policy outputs in the education sector

Table 2, shows the Hypothesis test on the effect of women organizations agenda setting on policy outputs in the education sector in Ghana and Liberia. Looking at the result it shows that shows that women organizations agenda setting has joint significant positive effect $F(1,677)=8453.559$, Adj. $R^{2}=0.962, p<0.05$ on policy outputs in the education sector in Ghana and Liberia. The t-statistics revealed that the individual parameter estimates are significant. This implies that an improvement on the women organizations agenda setting will bring about a corresponding increase on policy outputs in the education sector in Ghana and Liberia, all things being equal. 
The Adjusted R-Square of 0.962 reveals the explanatory power of women organizations agenda setting on policy outputs in the education sector. The result shows that $96.2 \%$ variation on policy outputs in the education sector is explained by women organizations agenda setting. The F-statistic reveals the combined significant influence of the all the independent variables on the dependent variable. Hence, from the result, it shows that the parameter of the general model is significant at 0.000 which is less than 0.05 level of significant. This means that the parameters estimates in a whole are statistically significant in explaining policy outputs in the education sector. Hence, the null hypothesis is rejected.

\section{Conclusion}

Women organizations agenda setting has positive effect on the policy outputs in the education sectors of Ghana and Liberia. Although, the level of women political participation and involvement in decision making roles are low in both countries, the impact of women organizations agenda setting is better felt in Liberia than in Ghana. This may not be unconnected with the fact that the country had a female President for twelve years, and this may have influenced the response rate of public officials and institutions to the inputs and demands of women organizations especially in their agenda setting roles.

In Ghana and Liberia, the number of women elected to the national legislature and the number of women who occupy key decision making roles in the public service remains low given their proportion of the population of both countries. This low level of women participation in politics and decision making roles may account for the low level of influence of women agenda setting on policy outputs in education sector of both countries. There is a need for both countries to create the enabling environment for inputs from women organizations to be better accommodated in the policy process. Adoption of quotas that would guarantee greater women representation in parliaments as well as appointment into cabinet positions, will create this required conducive environment.

\section{REFERENCES}

Afolabi, C. Y. (2019), "The Invisibility of Women's Organizations in Decision Making Process and Governance in Nigeria". Frontiers of Sociology, (January 2019), $\quad$ https://doi.org/10.3389/fsoc.2018.00040

African Women Power Network Reviews (2015), "Fourteen (14) Leading Organizations Changing the Lives of Nigerian Women and Girls". Available online at https://awpnetwork.com.

Agbalajobi, D. T. (2010), "Women's participation and the political process in Nigeria: Problems and prospects", African Journal of Political Science and International Relations, 4(2), 75-82.

Albrecht, J., and Arts, B. (2005), "Climate Policy Convergence in Europe: An Assessment Based on National Communications to the UNFCCC". Journal of European Public $\quad$ Policy 12 (5), 885-902.

Anderson, J. E. (1997), Public Policy-Making: An Introduction (3rd ed.) Boston: $\quad$ Houghton Miffilin Company.

Anyebe, A. A. (2018), “An Overview of Approaches to the Study of Public Policy". International Journal of Political Science (IJPS), 4(1), 08-17. http://dx.doi.org/10.20431/2454-9452.0401002

Arnesen, S. and Peters, Y. (2018), "The Legitimacy of Representation: How Descriptive, Formal, and Responsiveness Representation Affect the Acceptability of Political Decisions". Comparative Political Studies, 51(7), 868-899. DOI: $\quad$ 10.1177/0010414017720702

Asiedu, E., Branstette, C., Gaekwad-Babulal, N., and Malokele, N. (2018), "The Effect of Women's Representation in Parliament and the Passing of Gender Sensitive Policies", Available online at www.aeaweb.org/conference/preliminary/paper

Bobrow, D. (2006), "Policy Design: Ubiquitous, Necessary and Difficult". In Peters, G. B. and Pierre, J. (eds.). Handbook of Public Policy, (75-96). Thousand Oaks, CA: Sage.

Carley, S., and Miller, C. J. (2012), "Regulatory Stringency and Policy Drivers: A

Reassessment of

Renewable Portfolio Standards” Policy Studies Journal 40 (4), $\quad 730-56$.

Downs, A. (1957), An Economic Theory of Democracy. New York: Harper and Row 
Forester, J., (1984), "Bounded Rationality and the Politics of Muddling Through", Public Administration Review 44, 23-30.

Franceshet, S., Krook, M. L. and Piscopo, J. (2012), “Conceptualizing the Impact of Quotas” In Franceshet, S; Krook, M.L and Piscopo, J. (eds), The Impact of Gender Quotas. (3-26). New York: Oxford University Press,

Gerston, L. N. (2015), "What is Public policy and what is the legislature's role?" Accessed from www.leg.state.nv.us/Division/Research/LegInfo/....

Ghana Population (2019), Ghana Population 2018 (Demographics, maps, Graphs). Accessed An 17th September 2019 from http://worldpopulationreview.com/countries/ghana- population/

Grant, J. T., and Nathan, K. J. (2008), "Legislative Productivity of the US Congress, 1789-2004". Political Analysis 16 (3), 303-23.

Ishola, A., Nwogwugwu, N., Nwaodike, C. and Ogu, M. (2019), "Legislators' role in problem identification and agenda setting in public policy process in Nigeria". International Journal of Advanced Research, 7(3), 458-466. DOI URL: http://dx.doi.org/10.21474/IJAR01/8657.

Jahan, R (1996), The Elusive Agenda: Mainstreaming Women in Development. London: Zed Books.

Jahn, D., and Kuitto, K. (2011), "Taking Stock of Policy Performance in Central and Eastern Europe: Policy Outcomes Between Policy Reform, Transitional Pressure and International Influence", European Journal of Political Research 50 (6), 719-48.

Hibbing, J. R., and Theiss-Morse, E. (1995), Congress as Public Enemy: Public Attitudes Towards American Political Institutions. Cambridge: Cambridge University Press.

Holzinger, K., Knill, C. and Sommerer, T. (2011), "Is There Convergence of National Environmental Policies? An Analysis of Policy Outputs in 24 OECD Countries.” Environmental Politics 20 (1), 20-41.

Howlett, M. and Cashore, B. (2014), "Conceptualizing Public Policy”, In Engeli, I. and Allison, C. R. (eds.), Comparative Policy Studies: Conceptual and Methodological Challenges $\quad$ (17-34), Houndmills, UK: Palgrave Macmillan.

Howlett, M. and Lejano, R. P. (2012), "Tales from the Crypt: The Rise and Fall (and Rebirth?) of Policy Design”. Administration \& Society 45 (3), 357-81.

Howlett, M., and Cashore, B. (2009), "The Dependent Variable Problem in the Study of Policy Change: Understanding Policy Change as a Methodological Problem," Journal of Comparative Policy Analysis 11 (1), $33-46$.

Jones, B. D., and Baumgartner, F. R. (2012), "From There to Here: Punctuated Equilibrium to the General Punctuation Thesis to a Theory of Government Information Processing”, Policy Studies Journal 40 (1), 120.

Knill, C., Schulze, K. and Tosun, J. (2012), "Regulatory Policy Outputs and Impacts: $\quad$ Exploring a Complex Relationship" Regulation \& Governance 6 (4), 427-44.

May, P. J. (2003), "Policy Design and Implementation” In Peters, B. G. and Pierre, J. ～(eds.), Handbook of Public Administration, (223 - 233). London: SAGE.

Nwogwugwu, N. and Odedina, B. (2018), "Grassroots Women Political Participation and Poverty Reduction Strategies in Ghana And Nigeria". International Journal of Advanced Research, 6(9), 269-277. http://dx.doi.org/10.21474/IJAR01/7672

Page, M. T. (2018), “A new taxonomy for corruption in Nigeria. Carnegie Endowment for Peace”, 
Retrieved on $14^{\text {th }}$ October 2019 from

https://carnegieendowment.org/2018/07/17/new-taxonomy-for-

corruption-in-nigeria-pub-76811

Schneider, A., and Sidney, M. (2009), "What Is Next for Policy Design and Social

Construction Theory?"

Policy Studies Journal 37 (1), 103-19.

Walby, S (2005), "Gender mainstreaming: productive tensions in theory and practice". Social Politics 12(3), $1-25$.

Weible, C. M., Heikkila, T., deLeon, P. and Sabatier, P. A. (2012), "Understanding and Influencing the Policy Process". Policy Sciences 45(1), 1-21. 